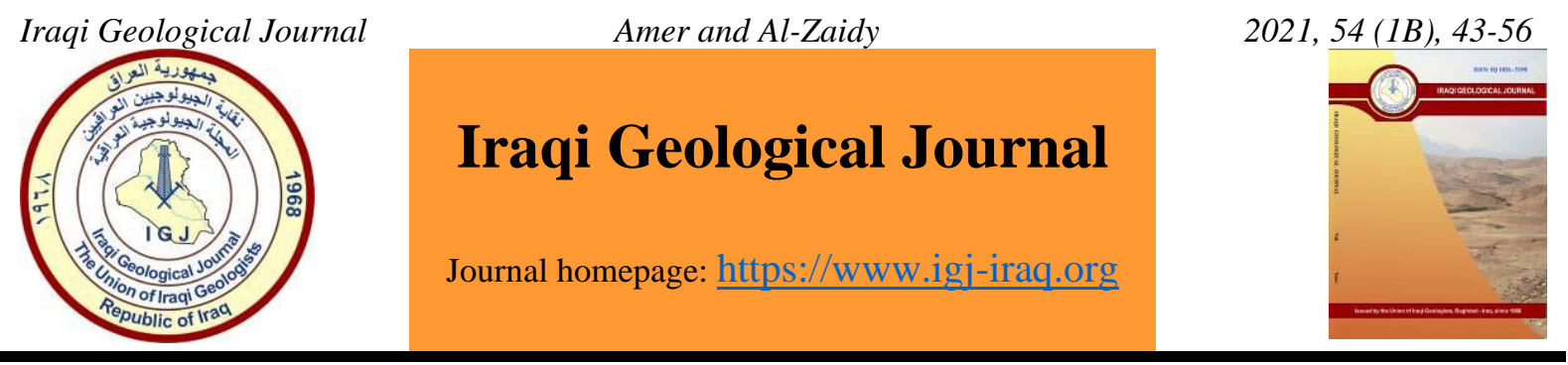

\title{
Facies Analysis and Depositional Stages of The Albian-Aptian Succession in Balad Oil Field, Central Iraq
}

\author{
Zainab Amer ${ }^{1}$ and Aiad Ali Hussien Al-Zaidy ${ }^{2, *}$ \\ ${ }^{1}$ Civil Engineering Department, Al-Esraa University College, Baghdad, Iraq \\ ${ }^{2}$ Department of Geology, College of Science, University of Baghdad, Baghdad, Iraq \\ *Correspondence: aiad.alzaidy@gmail.com
}

Received: 31 October 2020; Accepted: 13 December 2020; Published: 28 February 2021

\begin{abstract}
Carbonate-clastic succession which includes the Shu'aiba, Nahr Umr and Mauddud formations are representing a part of the Barremian-Aptian Sequence (Wasi'a Group). The present study includes three boreholes (Ba-1, 4 and 8 ) within the Balad Oil Field. The study area is located in central Iraq. This field represents a subsurface anticline with a northwest to southeast direction axis within the Mesopotamian Zone. Eight types of microfacies were recognized in the succession of the Mauddud and Shu'aiba formations. These microfacies represent shallow open marine, restricted and semi-restricted, reef - back reef, deep open marine and basinal depositional environments. While Nahr Umr Formation includes two successions, the first is the upper unit which is characterized by shale dominated rocks and the second is the lower unit which is characterized by sand-dominated rocks. Four major lithofacies were recognized in these two successions, they represent four depositional environments which are distributary channel, bay fill, delta plain and prodelta. The Albian-Aptian sequence was deposited during three cycles overlying the regional unconformity below the Shu'aiba Formation, the Zubair Formation, and ended with local unconformity with the Ahmadi Formation. The first stage is represented by deposition of Shu'aiba Formation during the sea-level rise after regression stage during the Zubair deposition which deposition in delta association facies. The second stage was showed a regressed of deposit the delta system above the shallow open marine of the Shu'aiba Formation, where the succession became characterized by mud dominated rock with fissile and organic material. The third depositional stage is represented by the continuation of sea-level rise. This transgression leads to the building of carbonate ramp of the Mauddud Formation above the deltaic system of Nahr Umr Formation with a conformable surface. The Mauddud depositional stage was represented by two cycles of transgression succession, where appeared deepening upward in both cycles. The unconformity between these formations have been determined by observing the glauconite mineral and detected by log response in depth $2880 \mathrm{~m}$ in well Ba-1.
\end{abstract}

Keywords: Facies analysis; Depositional stages; Albian-Aptian Succession; Balad Oilfield; Iraq

\section{Introduction}

Carbonate-clastic succession which includes the Shu'aiba, Nahr Umr and Mauddud formations represent parts of the Barremian-Aptian Sequence (Wasi'a Group). The present study includes three boreholes (Ba-1, 4 and 8) within the Balad Oilfield. The study area is located in central Iraq. This field represents a subsurface anticline with a northwest to southeast direction axis within the Mesopotamian Zone according to tectonic subdivisions of Fouad (2014) (Fig.1).

DOI: $10.46717 /$ igj.54.1B.4Ms-2021-02-22 


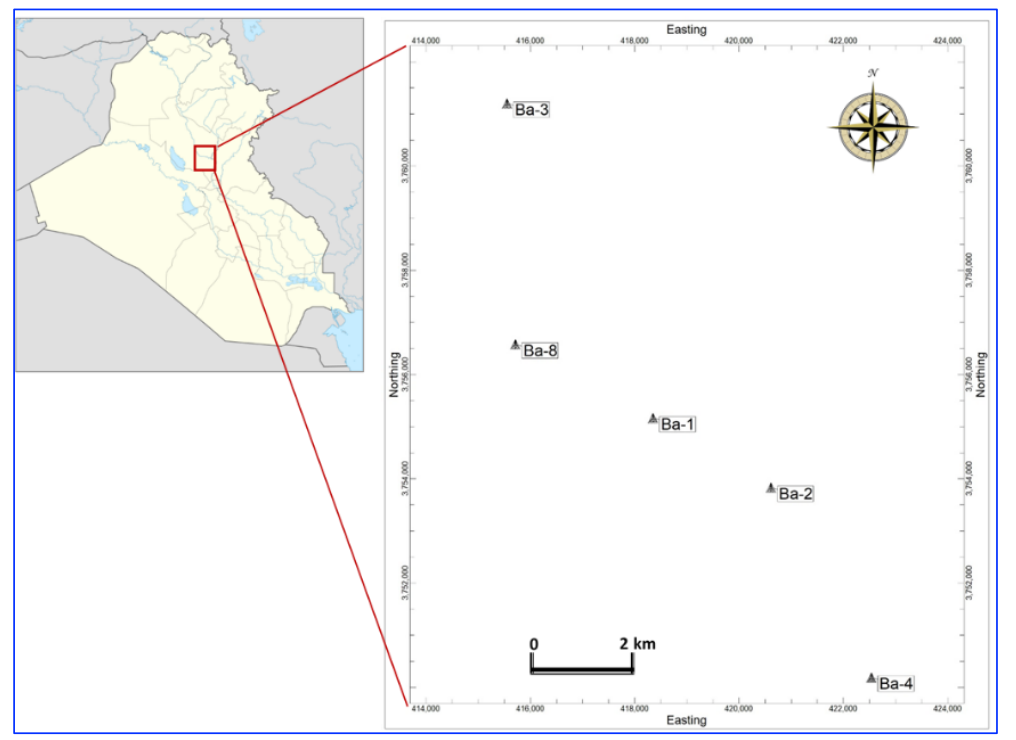

Fig.1. Location map shows the distribution of studied boreholes

The Shu'aiba Formation was first defined by Owen and Nasr (1958 in Bellen et al., 1959) from well Zubair-3 in S Iraq. It comprises $62 \mathrm{~m}$ of pseudo-oolitic limestone, sometimes sandy, fine-grained organodetrital limestone grading into the chalky limestone and limestone with shale streaks near the top. It contains Orbitolina cf. discoidea GRAS, Choffatella decipiens SCHLUMBERGER (at the base only) and globigerinids which (together with the stratigraphic position of the formation) indicate an Aptian age (Bellen et al., 1959). The formation overlies and passes laterally into the Zubair Formation with a conformable and gradational contact. The upper contact is associated with a 6 Ma break in Kuwait (Douban and Medhadi, 1999).

The Nahr Umr Formation was defined by Glynn Jones (1948 in Bellen et al., 1959) from the Nahr Umr structure in South Iraq. The two major depocenters in Central and Southern Iraq correspond to areas which received clastics from the Rutba Uplift and the Arabian Shield. In its type area in Southern Iraq, the Nahr Umr Formation comprises black shale bedded with medium to fine grained sandstones with lignite, amber, and pyrite. The proportion of sand in the formation increases towards the Salman Zone (Jassim and Buday, 2006). Nahr Umr Formation was divided into three main rock units by AlGarbawi and Al-Shahwan (2019), these are upper Nahr Umr unit (NRA), middle Nahr Umr unit (NRB) and lower Nahr-Umr unit (NRB). The Mauddud Formation includes the upper part of the Qamchuqa Formation and is the most widespread lower Cretaceous formation in Iraq. Its thickness varies due to lateral facies changes and erosional truncation. At outcrop in NE Iraq, the Qamchuqa Formation comprises organodetrital, detrital and locally argillaceous limestones with variable degrees of dolomitization. In some areas fresh- or brackish-water limestone beds were reported (Bellen et al., 1959). In Southern Iraq, the Mauddud Formation comprises frequently dolomitized organodetrital limestone (Buday, 1980). The present study involves microfacies analysis and paleoenvironments development of the Shaiba, Nahr Umr and Mauddud formations in Balad oilfield.

\section{Materials and Methods}

The current study was completed in three stages:

- Sampling and description stage; this stage is represented by going to the North Oil Company (NOC) where the samples are collected.

- Laboratory stage: during this stage the samples were chosen and made thin sections. The petrographic study and microfacies analysis are based on the study of thin sections of cuttings and core from the selected boreholes from Balad Oilfield. 
- In the third stage, study the available well logs were utilized in calculated the petrophysical parameters and interpreting them.

\section{Stratigraphic Setting}

According to Iraq geological map, issued by the State Establishment of Geological Survey and Mining in 1990, the study area is flat land with some simple upland which range from $48-58 \mathrm{~m}$ (Sissakian, 2000). The elevation of the study area increases towards the north-east. The study area is characterized by the agricultural regions where it has many orchards, irrigation projects, marshes and swamps, as well as the presence of residential areas, civilian and military establishments. The study area is covered by recent and Pleistocene sediments represented by alluvial deposits and river terraces, where the studied succession became thicker to the south toward near Ba-4 (Fig. 2).

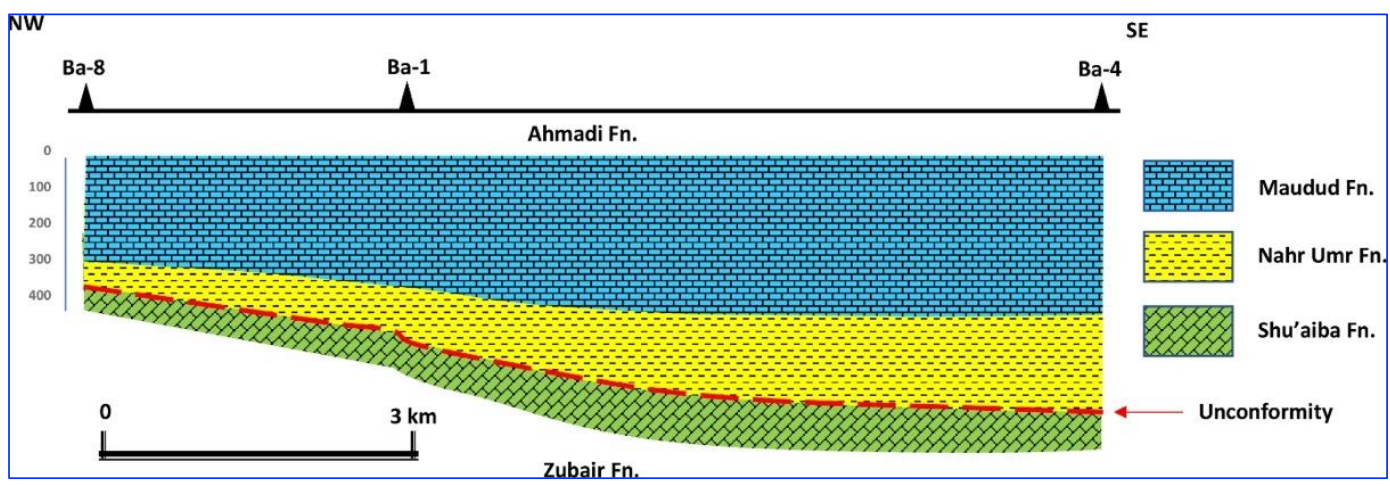

Fig. 2. Lithologic cross section shows thickness and distribution of the studied formations

The separation of Arabian Plate from the African Continent in the Oligocene caused rotational motion of Arabian Plate toward the north and north-east. This led to collision between the Arabian Plate with the Eurasian Plate from north and north-east, as a result of compression forces which affected on the Arabian Plate, led to compress the Mesopotamian basin. As a result, the axis of Balad Oilfield which lies close to the Foot Hills, shifted parallel trend to elongate axis of Zagros Mountains (northwest and southeast) directions, also emergence of a dip and strike directions secondary tension faults (Muhsin, 2012). The Shu'aiba Formation overlies and passes laterally into the Zubair Formation with a conformable and gradational contact deposited in delta association facies (Al-Zaidy, 2019). The thickness ranges between $30 \mathrm{~m}$ in the west (Ba-8) and $100 \mathrm{~m}$ to the north near Ba-3 (Fig. 3). The Nahr Umr Formation is gradationally overlain by the Mauddud Formation; the contact is taken at the base of a $2 \mathrm{~m}$ thin-bedded limestone bed. The Nahr Umr Formation overlies the Saggar Formation. The formation's thickness is ranging from $22 \mathrm{~m}$ to $54 \mathrm{~m}$ in the east of Rutba (Jassim and Buday, 2006), while in the study area the thickness is ranging from $30 \mathrm{~m}$ near Ba-3 and Ba- 8 to $120 \mathrm{~m}$ near Ba-4 (Fig.4).The lower contact of the Mauddud (Upper Qamchuqa) Formation is conformable and gradational with the Nahr Umr, Lower Balambo or Lower Sarmord formations. The upper contact is marked by a break and is either nonsequential or unconformable; it is an unconformity in N Central, N and NE part of Iraq (Jassim and Buday, 2006). The thickness of the Maudud Formation is ranging from 80m near Ba-3 to 190m near Ba-2 (Fig.5). The facies analysis of the Mauddud Formation shows the dominance of open marine facies in the upper and middle parts of the formation, whereas mid-ramp facies occupies the lower part. The shoal facies represent approximately continuous or pinchoutunits among wells of Badra Oilfield (Faisal and Mahdi, 2020). 


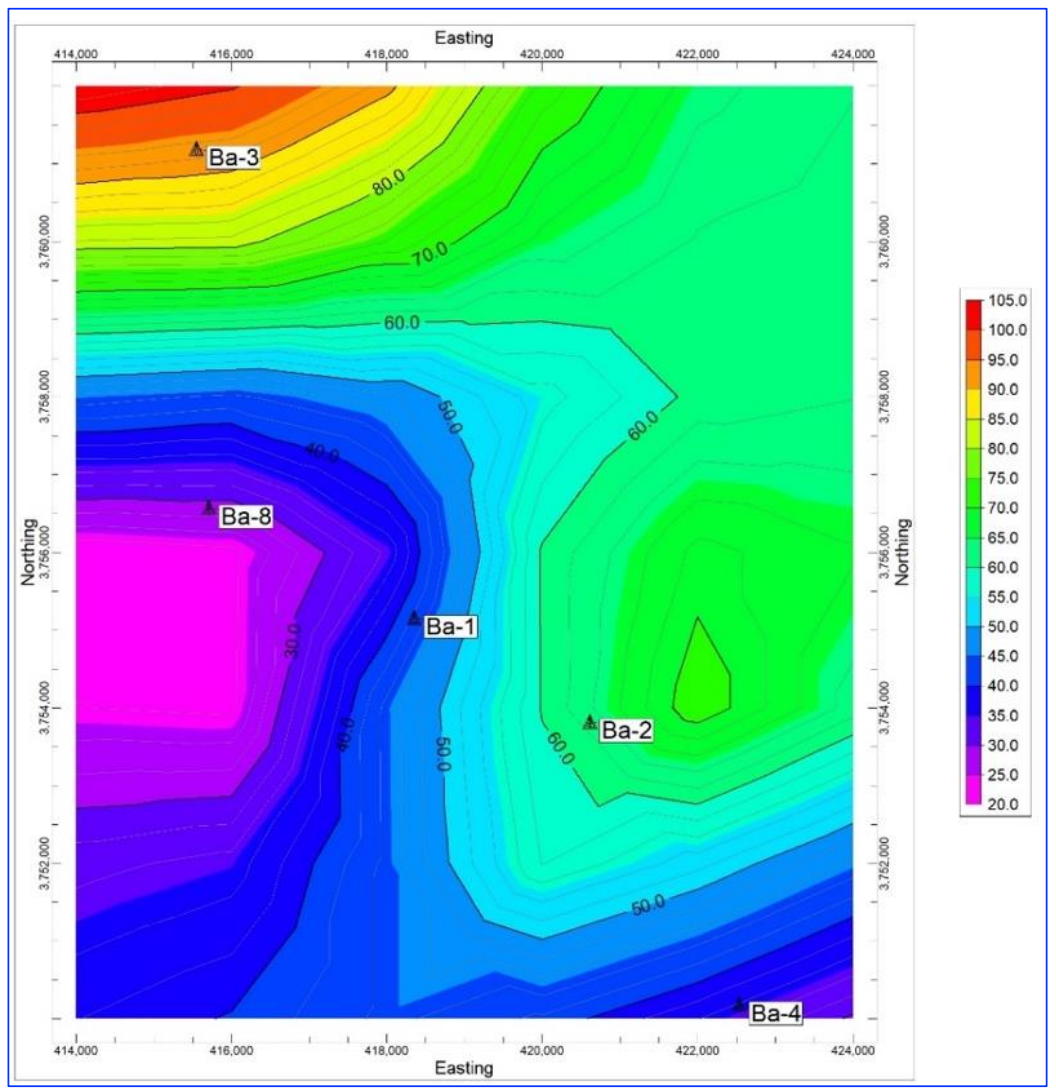

Fig. 3. Isopach map of the Shu'aiba Formation in studied wells $($ C.I. $=2 \mathrm{~m})$

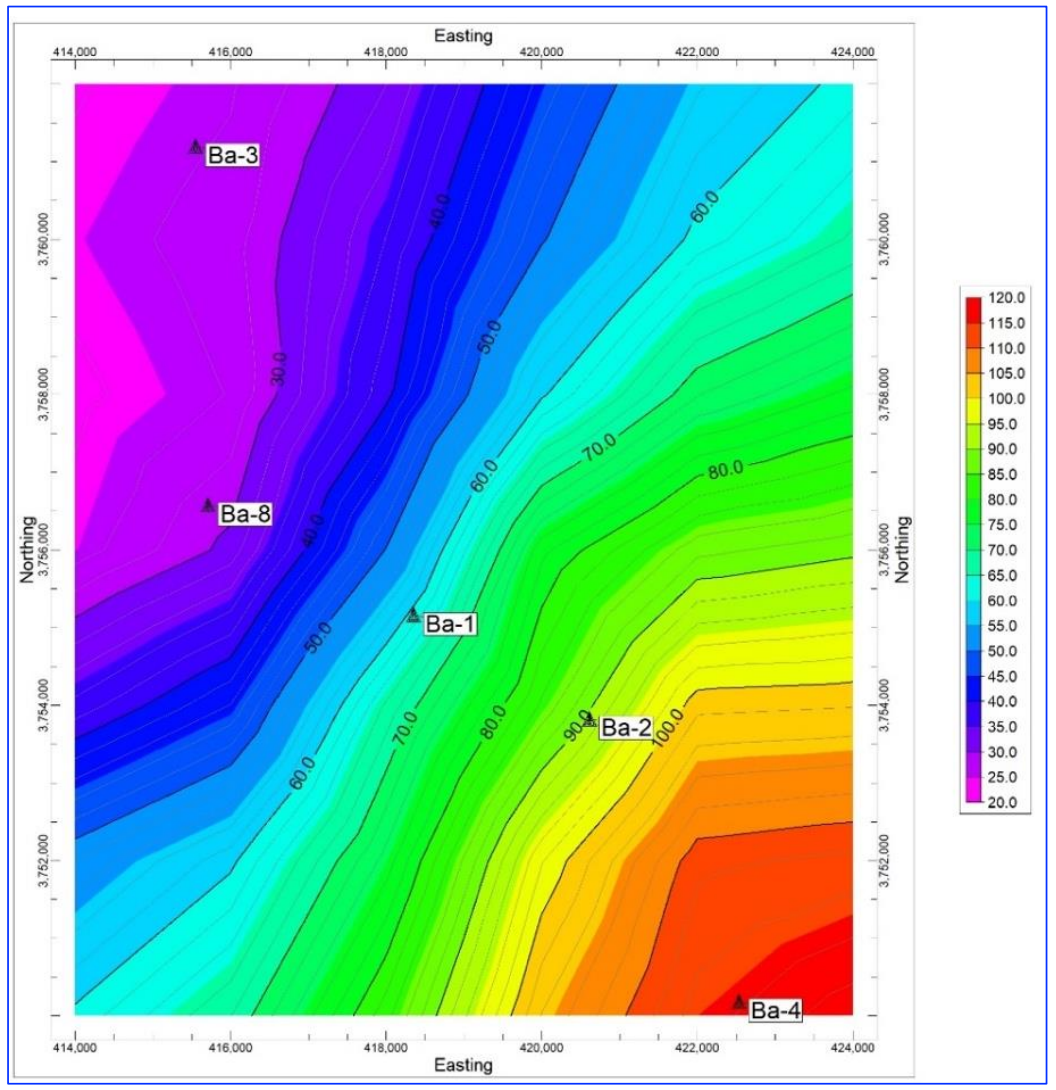

Fig. 4. Isopach map of the Nahr Umr Formation in studied wells $($ C.I. $=2 \mathrm{~m})$ 


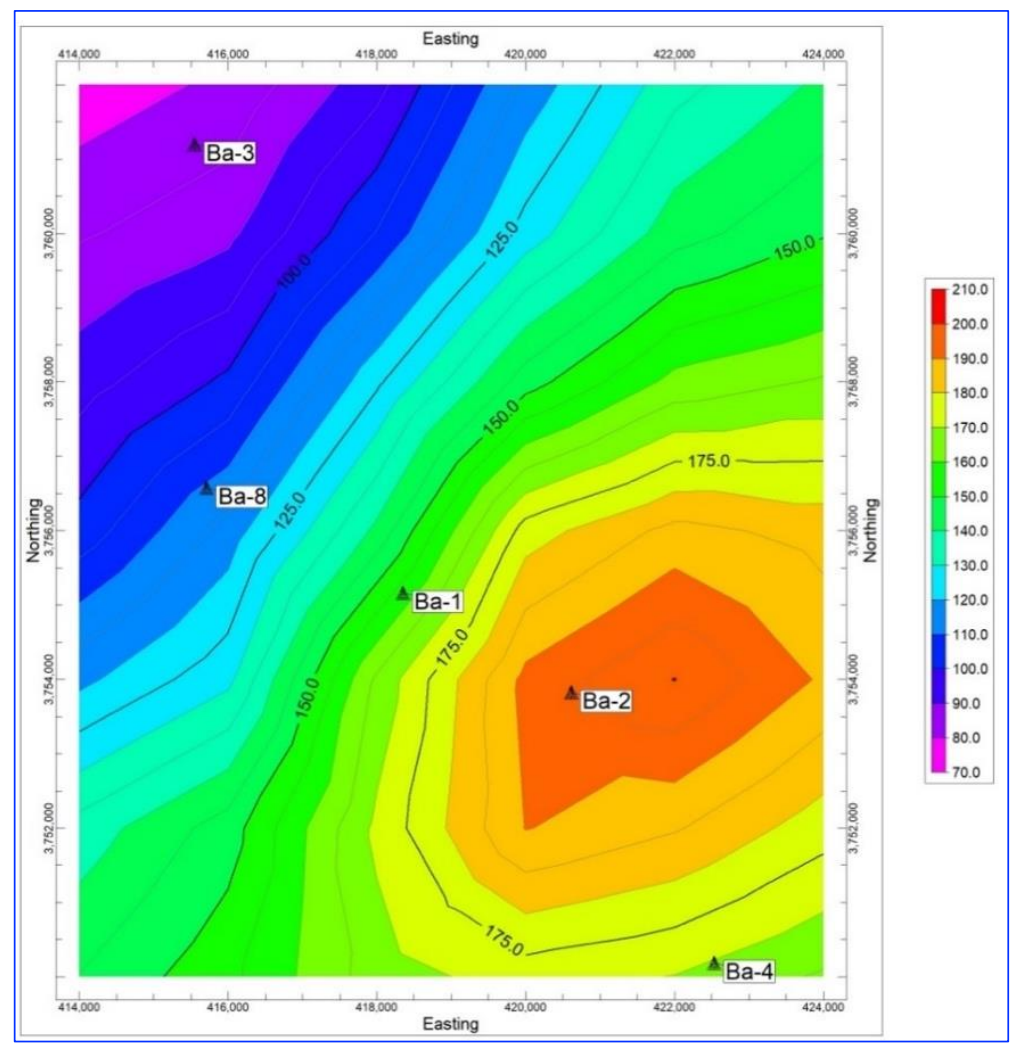

Fig. 5. Isopach map of the Mauddud Formation in studied wells (C.I. $=5 \mathrm{~m})$

\section{Results}

\subsection{Microfacies and Lithofacies Analyses}

\subsubsection{Microfacies of Shu'aiba and Mauddud}

The textures and fabric of the carbonate rocks for Shu'aiba and Mauddud formations are classified according to Embry and Klovan's classification (1971) modified from Dunham (1962). The approach of Burchette and Brittons (1985) in grouping facies types as "association" rather than a single type or class was followed. The facies associations were compared with the models of standard microfacies and depositional environment belt of carbonates proposed by Wilson (1975) and Flugel (2010). Several types of microfacies were recognized in the succession of the Mauddud and Shu'aiba formations; their characteristic grain types and depositional texture enabled the recognition of paleoenvironment.

\section{- Microfacies (A): Orbitolina - wackestone to packstone}

It is the main microfacies type observed in all studied well within Mauddud and Shu'aiba formations. This microfacies contains Orbitolina sp., Trocholina sp., Echinoderm stem and spin, Gastropods, Crinoids, and rudist bioclast (Fig.6A). This facies is mainly composed of Orbitiolina to represent the Standard Microfacies Type ten (MFS10) within Facies Zone type seven (FZ7) according to the abundance of benthic foraminifera, to refer the deposition in shallow open marine.

- Microfacies (B): Miliolids packstone to grainstone

The main allochems has been identified in this microfacies are Miliolid., Trocholina sp., Pseudolituonella sp., Nezzazata sp., and bioclast of Gastropods, Echinoderm, in addition to peloidal 
fragments (Fig.6B). The main constituents are miliolids and benthic foraminifera refer to the Standard Microfacies eighteen (MFS18) within Facies Zone eight (FZ8), which deposited in restricted shallow marine environment.

- Microfacies(C): Oligostigenide wackestone to packestone

This microfacies containing oligosteginid as the main allochem with calcisphere and globigerina, associated small benthic foraminifera with few red algae (Fig.7A). These inclusions refer to the Standard Microfacies three (MFS3) within Facies Zone 3 (FZ3), which deposited in deep open marine or deep shelf environment.

- Microfacies (D): Peloidal wackestone to packstone

This microfacies consists mainly of peloids with rudist fragments, calcareous algae and miliolids being the less abundant. Peloidal wackestone to packstone rounded grains are inferred, from their biform size, ovoid shape where the dominance of relatively coarse to fine (sand sized) and moderate sorted peloids (Fig.7B). This microfacies may represent MFS16 within FZ8 which deposited in restricted shallow marine with moderate water circulation.

- Microfacies(E): Peloidal Orbitolinid packstone

Pelletal wackestone to packstone is characterized by the abundance of the uniformly of small particle size and consistent shape of these grains (silt sized well sorted pellets) (Fig.8A). In this microfacies most grains are coated bioclasts, exhibit micrite envelopes or are completely micritized as MFS11 within FZ6 which deposited in semi-restricted shallow marine environment.

- Microfacies (F): Intraclasts brecciated wackstone - packstone

Two types of this microfacies were distinguished in the succession bioclasts (rudist and other shell fragments) (Fig.8B), and mudstone to wackstone shell fragment packstone with micro convolute structure. This microfacies is represents MFS6 within the zone FZ4 which reflect the deposition as brecciated slope deposits.

- Microfacies (G): Rudist framestone to rudstone

This is a less common microfacies distinguished in most wells. It is composed of rudist fragments and other shell fragments (gastropod and mollusk) (Fig.9A). This microfacies is identified as backreef to reef environment. This unique microfacies is represents a MF7 within FZ5 as reef and backreef.

- Microfacies (H): Basinal green shale

This facies is appeared in the upper part of the Mauddud Formation as ooze, calcisphere shale and marly limestone (Fig.9B). This faceis is observed in the reflected gamma ray log response in addition to thin section diagnostic. The green shale and marly limestone microfacies are refer to MFS1 within FZ1 and FZ2 which deposited in basinal environment.
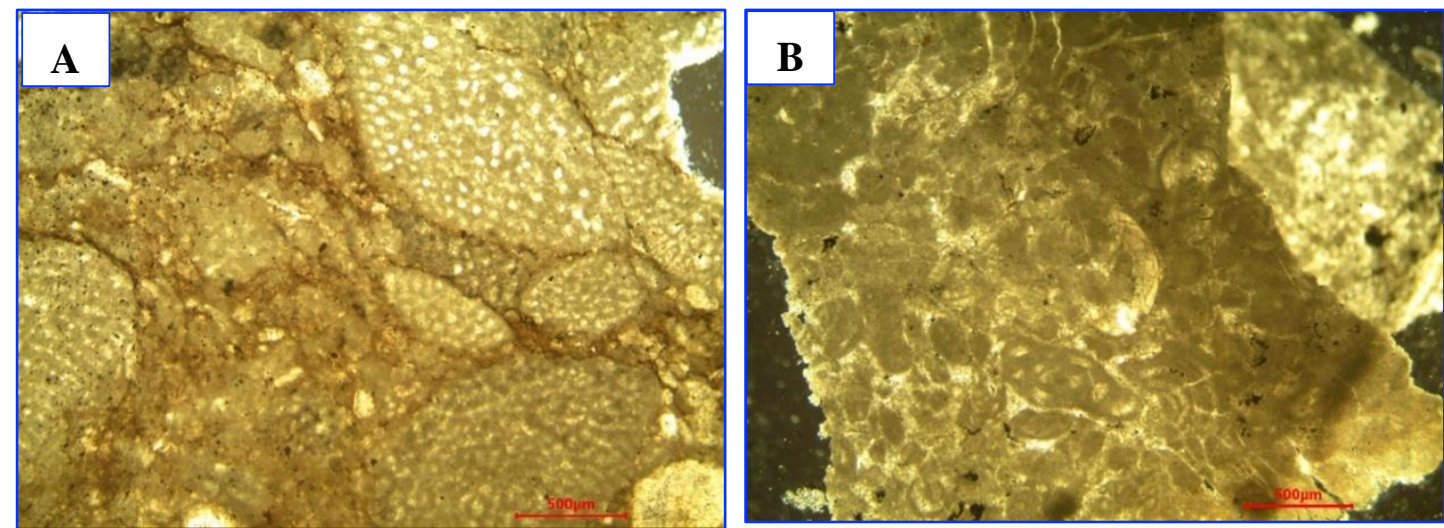

Fig. 6. Microfacies types A. Orbitolina - wackestone to packstone (Ba-1/3108m), B. Miliolids packstone to grainstone (Ba-8 / 2925m) 

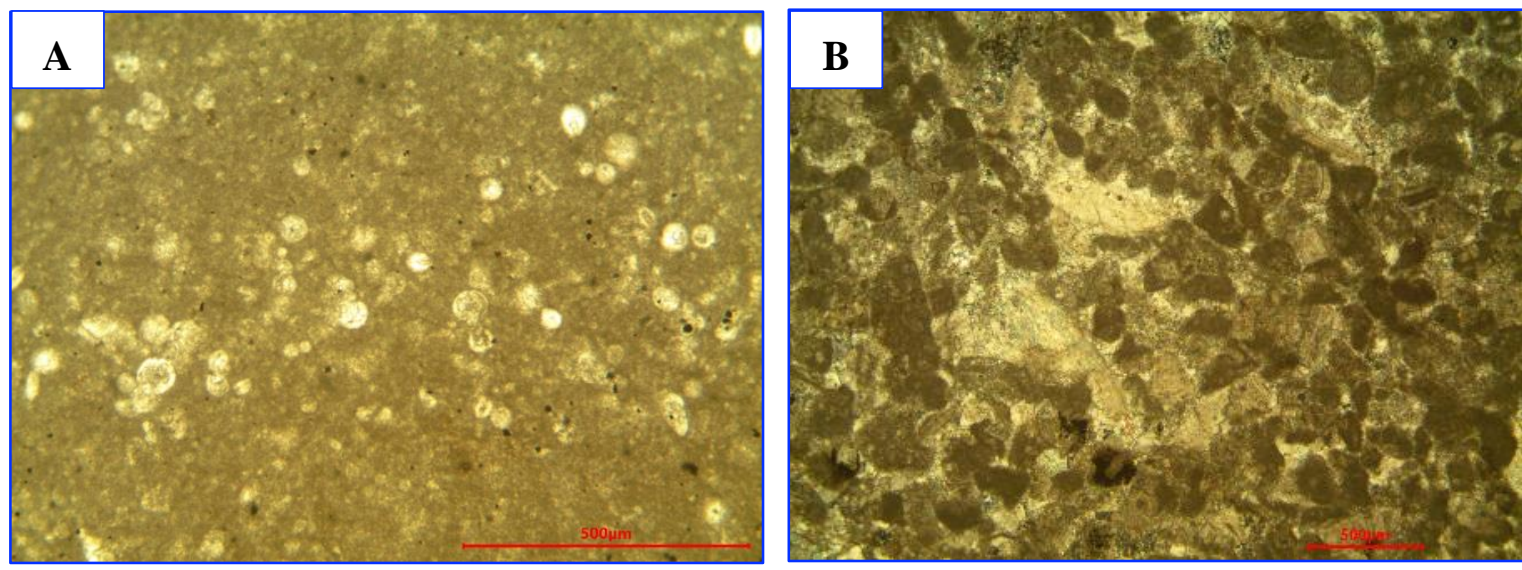

Fig.7. Microfacies types A. Oligostigenide wackestone to packestone (Ba-1/2864m), B. Peloidal wackestone to packstone $(\mathrm{Ba}-1 / 2905 \mathrm{~m})$
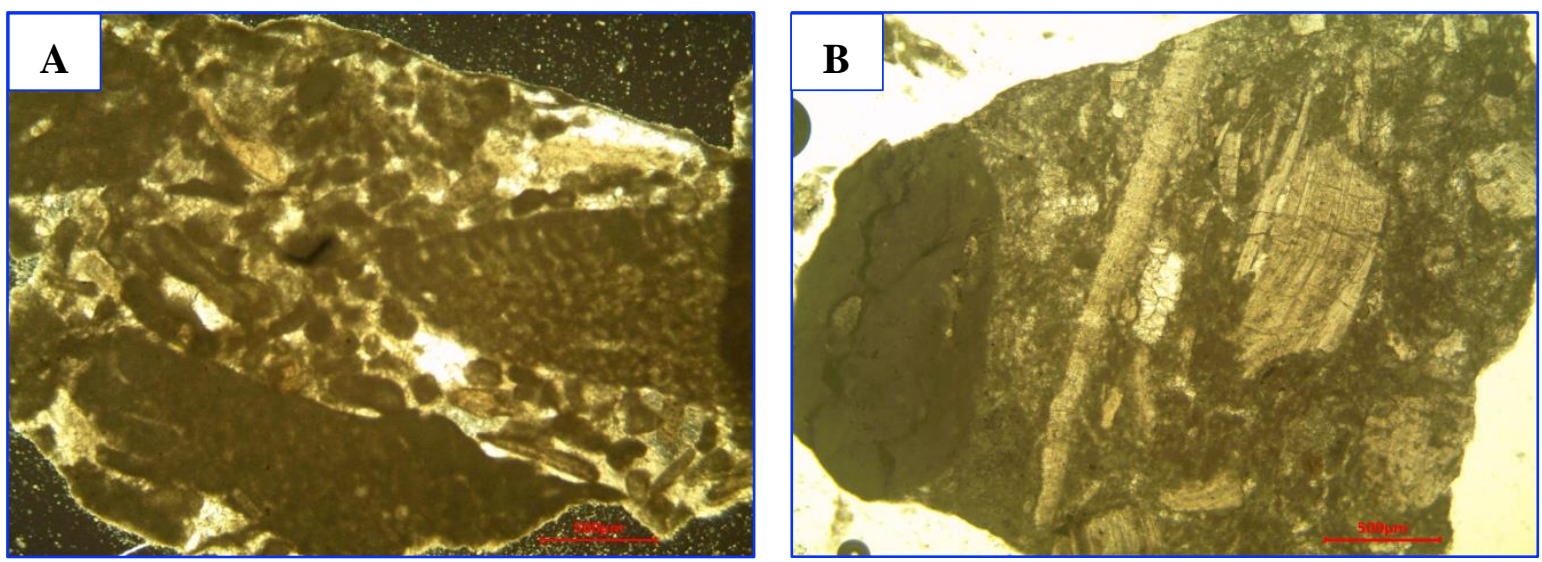

Fig. 8. Microfacies types A. Peloidal / orbitolinid packstone (Ba-8/3071m), B. Intraclasts brecciated wackstone packstone (Ba-8(2970m)
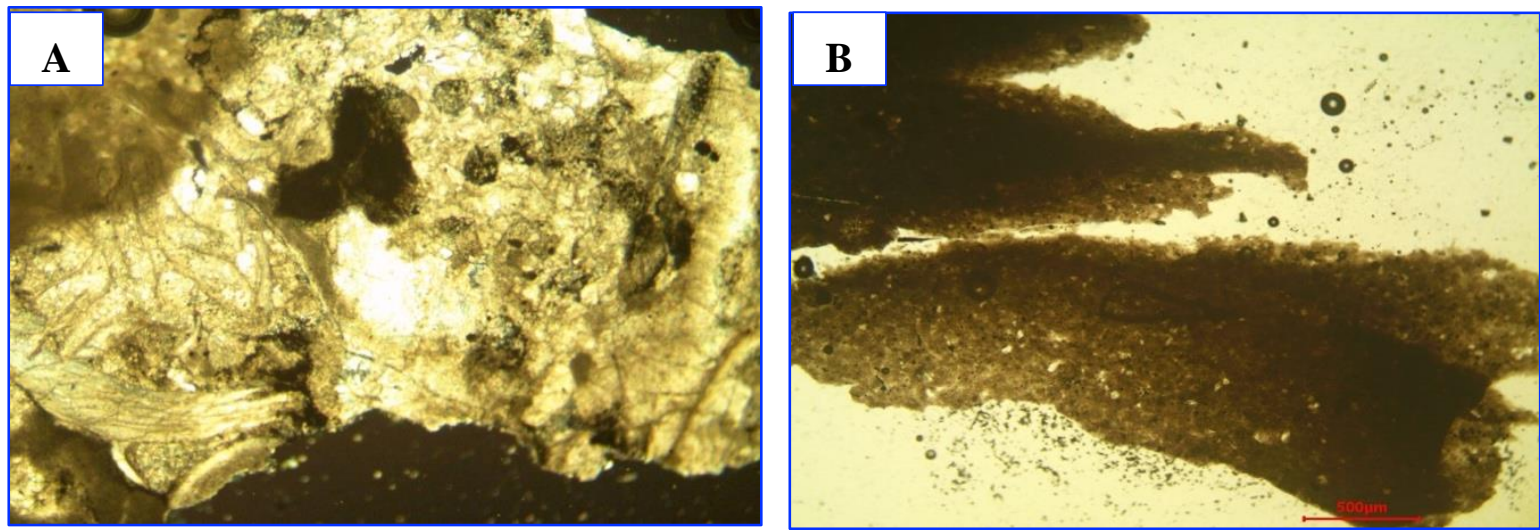

Fig.9. Microfacies A. Rudist framestone to rudstone (Ba-1/2990m), B. Basinal shale (Ba-4/3114m)

\subsection{Nahr Umr Lithofacies}

Two types of successions are observed in the Nahr Umr Formation; the first is the upper unit which is characterized by shale dominated rocks and the second is the lower unit which characterized by sand dominated rocks. According to the classification of siliciclastic rocks for Folk et al. (1970) and Pettijohn et al. (1973), the Nahr Umr clastic rocks are ranging from quartz arenite to mudstone. In addition to the standard dimensions which used in the descripted of the sedimentary particle size, shape and sorting types after Powers (1953), with response of gamma ray and spontaneous potential well logs 
to determine the sequence boundaries and paleoenvironment. There are four major lithofacies were recognized in the succession of the Nahr Umr Formation according to the petrographic examination with gamma ray and spontaneous potential well logs. Four main depositional environments that are distinguished from the successive of these lithofacies are distributary channel, bay fill, delta plain and prodelta (Figs. 13, 14, 15 and 16).

\subsubsection{Sandstone rock unit}

- Quartz arenite sandstone lithofacies (LF1)

The sandstone in these facies is composed of more than $90 \%$ of quartz to classify according to Folk (1973) as quartz arenite sandstone. There are two sublithofacies in this succession:

- $\operatorname{LF}(1 \mathrm{a})$

Well sorted quartz arenite sublithofacies which represents the fine grained well sorted sand dominated rocks with angular to sub-angular grains shape (Fig.10A). This appeared in the upper part of lower unit as very low gamma ray values with bell shape of gamma ray log with high oil show.

\section{- $\operatorname{LF}(1 b)$}

Poorly sorted quartz arenite sublithofacies which represents wide range of grain size of sandstone (fine-coarse) and well-rounded to sub-rounded grain shape, within the sand dominated rocks (Fig.10B). The sandstone in this facies is containing of more than $90 \%$ of quartz to classify as quartz arenite which appeared in the lower part of the lower unit. This characterized by poorly sorted, very low gamma ray values which increasing upward with funnel shape of gamma ray log with high oil show.

- Graywacke sandstone lithofacies (LF2)

This lithofacies represents the muddy sand dominated rocks which mainly composed of quartz mineral. It is characterized by poorly sorted graywacke sandstone (Fig.11A), with moderate values of gamma ray (funnel shape). This lithofacies is appeared in the upper unit of the Nahr Umr Formation, in addition to muddy parts of the lower unit.

\subsubsection{Shale rock}

- Sandy shale lithofacies (LF3)

This facies is appeared in the shale member as sand lenses, which characterized by high gamma ray values with funnel shape. The main composition of this facies is shale dominated rock with quartz grains angular shape (Fig.11B).

\section{- Shale lithfacies (LF4)}

This facies represents the upper unit of the Nahr Umr Formation. It is characterized by main composition of shale (Fig.12), with high gamma ray values with bell shape.
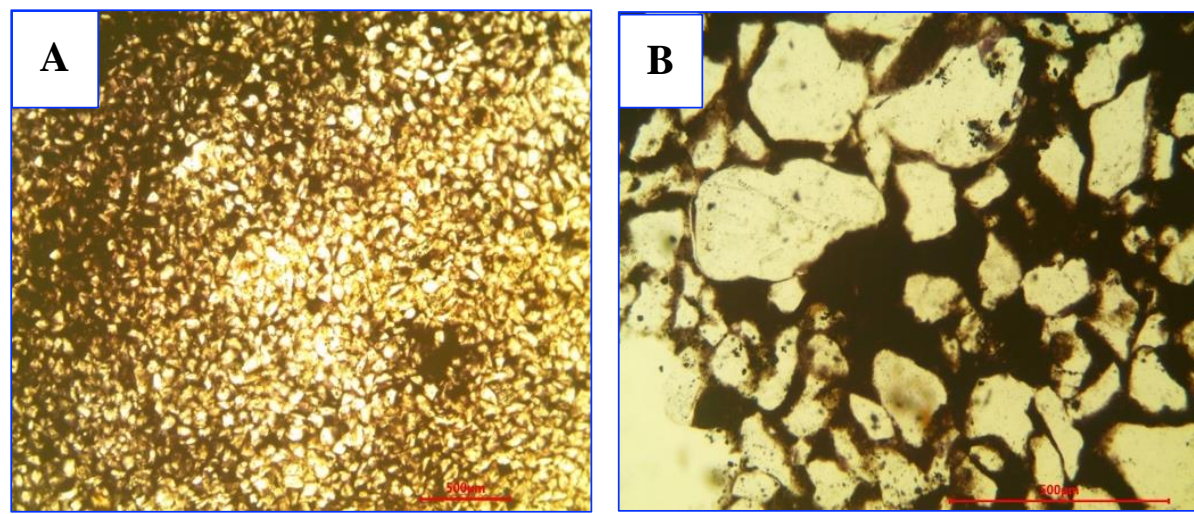

Fig.10. Lithofacies types A. Well sorted quartz arenite sublithofacies (Ba-1/3160m), B. Poorly sorted Quartz arenite sublithofacies $(\mathrm{Ba}-4 / 3064 \mathrm{~m})$ 

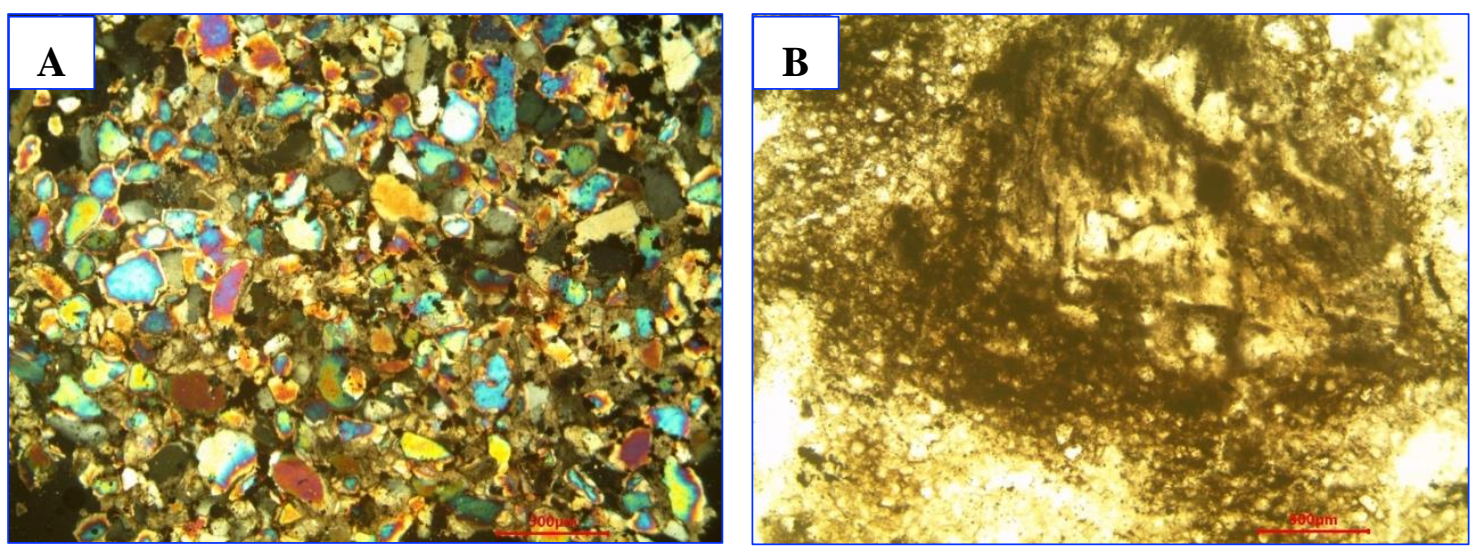

Fig.11 .Lithofacies types A. Graywacke sandstone lithofacies (Ba-4/3040), B. Sandy shale Lithofacies (Ba-1/3160)

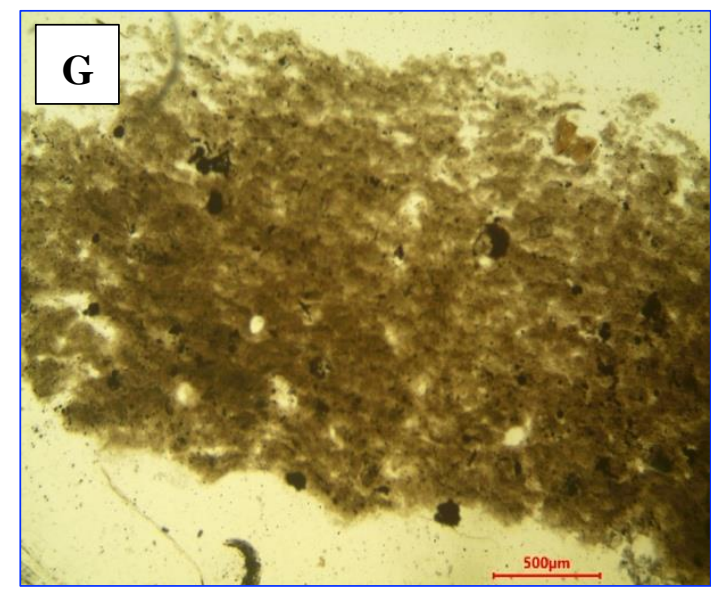

Fig.12. Shale lithfacies $(\mathrm{Ba}-4 / 3030)$

\section{Conclusions}

The studied succession was deposited during the Albian-Aptian Stage within Early Cretaceous Epoch. The sea-wide transgressive over the whole area led to progress the clastic systems toward their resources. This sequence was deposited during three cycles overlying the regional unconformity below the Shu'aiba Formation with Zubair Formation, and ended with local unconformity with Ahmadi Formation:

\subsection{The first Stage}

It is represented by deposition of the Shu'aiba Formation during the sea level rise after regression stage during the Zubair deposition in delta association facies. In all studied wells the Shu'aiba succession are characterized by heterogeneity microfacies as underlying of shallow open marine association with restricted shallow marine association. This refers to the transgression stage overlying the unconformity above of the Zubair Formation.

\subsection{The second Stage}

During this stage, the sea level was regressed to deposit the delta system above the shallow open marine of the Shu'aiba Formation, where the succession became characterized by mud-dominated rock 
with fissile and organic material. This succession of the Nahr Umr is divided into two units based on the presence of sandstone and shale bodies. The lower is the delta plain association facies with the main composition of mudstone and organic material. On the contrary, the upper member is characterized by coarsening upward with an alternative of mudstone and sandstone for the distributary channel deposit which is separated by bay fill deposit.

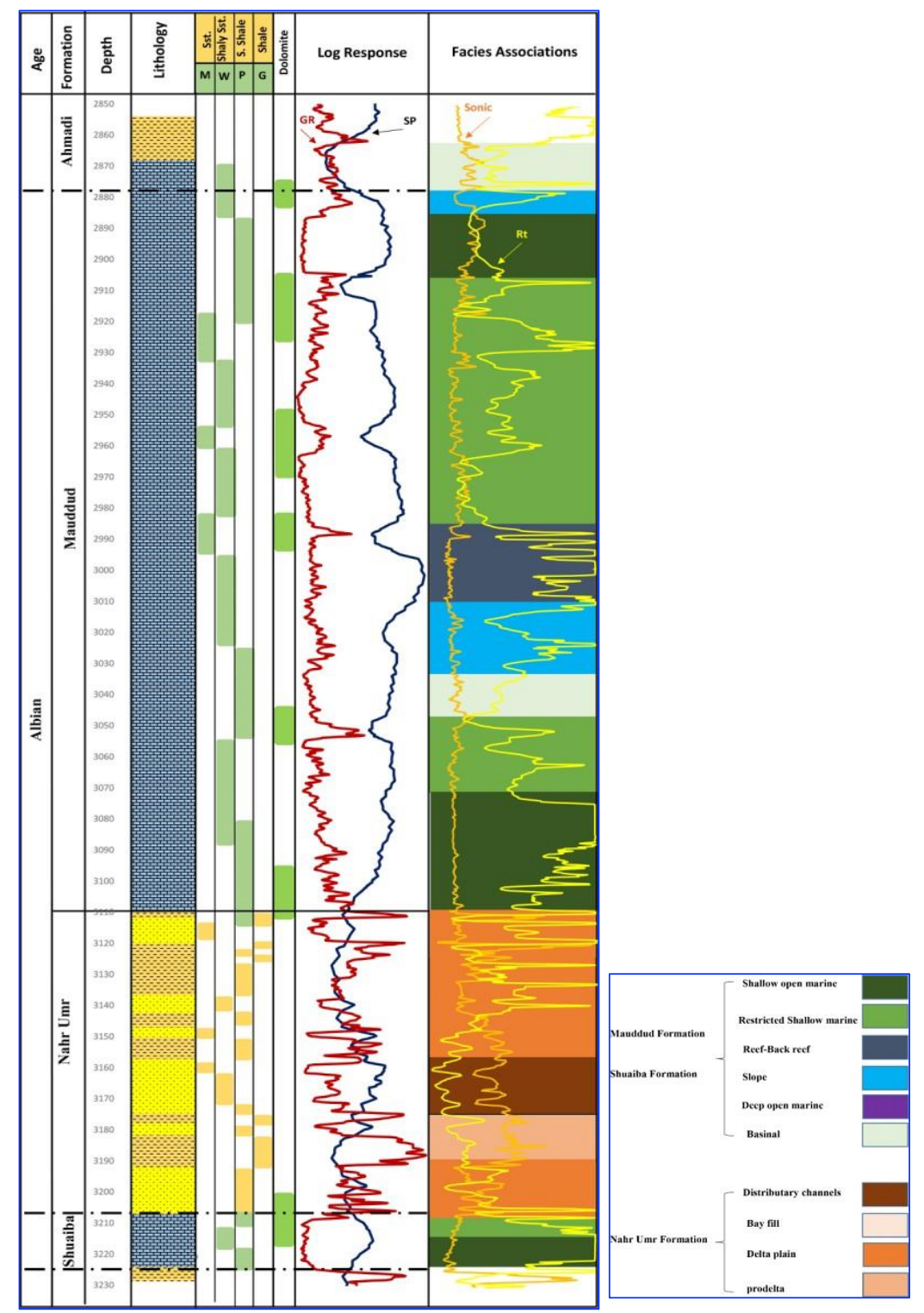

Fig.13. Columnar section (well $\mathrm{Ba}-1$ ) shows the lithofacies distribution and major depositional environments

\subsection{The third Stage}

This stage is represented by the continuation of sea level rise. That is leads to the building of carbonate ramp of Mauddud Formation above the deltaic system of Nahr Umr Formation with a conformable surface. The Mauddud depositional stage was represented by two cycles of transgression succession, where appeared deepening upward in both cycles. The first cycle is showing the deepest area to the southeast part of the studied area, where the basinal and slope facies appeared onlapping the shallow facies in well Ba-4. On the contrary, the second cycle is appeared as the depositional center (deepest area) to the northwest area. These are represented by the occurrence of deep and slope facies overlying the shallow facies in well Ba-8. These two cycles are separated by reef and backreef facies, which indicate to still stand sea level was took place at this period of deposition. At the end of the third 
stage, the sea level was fall to mark the end of the deposition of studied succession with regional unconformity with Ahmadi Formation. The unconformity between these formations have been determined by observing the glauconite mineral and detected by $\log$ response in depth $2880 \mathrm{~m}$ well $\mathrm{Ba}-$

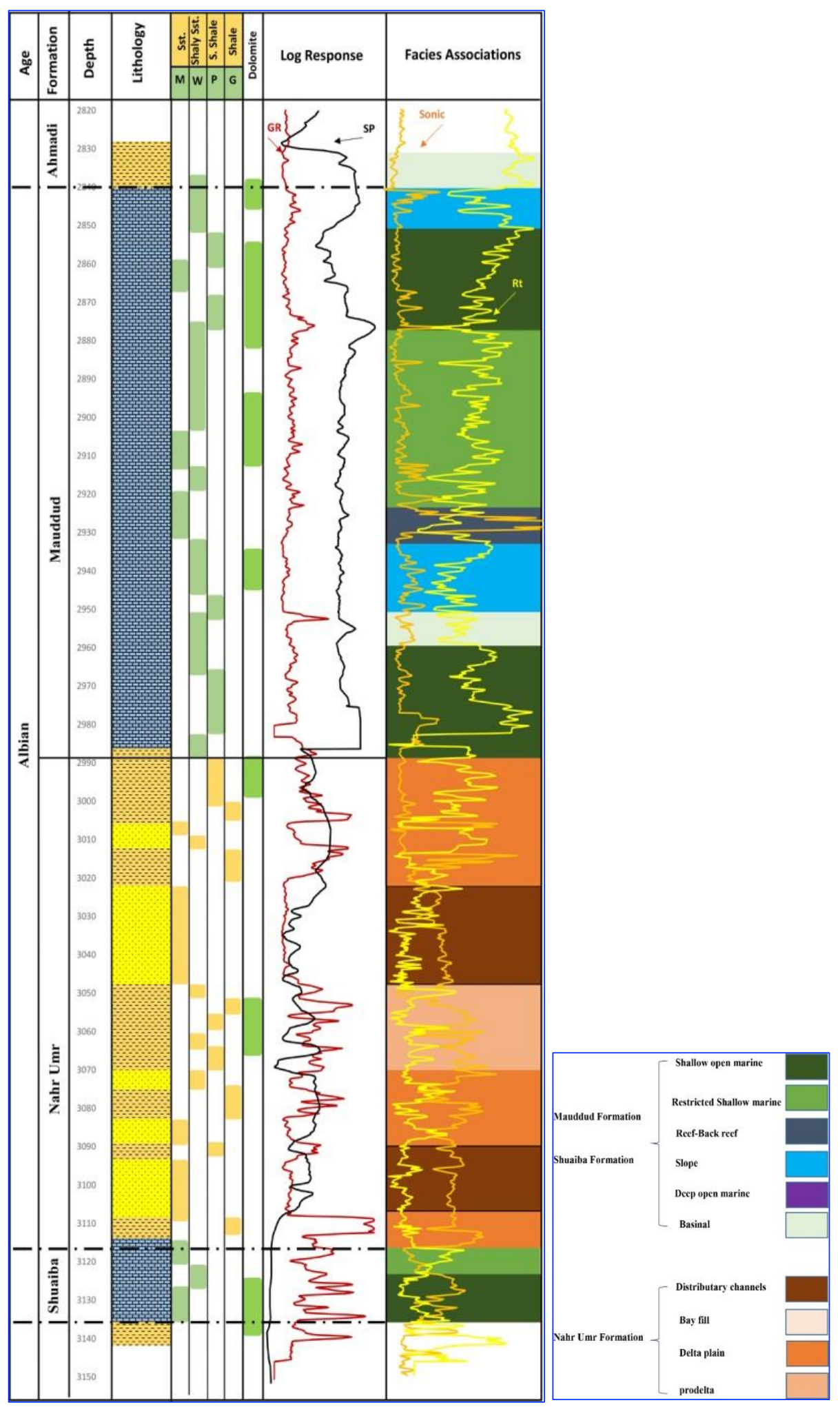

Fig.14. Columnar section (well Ba-4) shows the lithofacies distribution and major depositional environments 


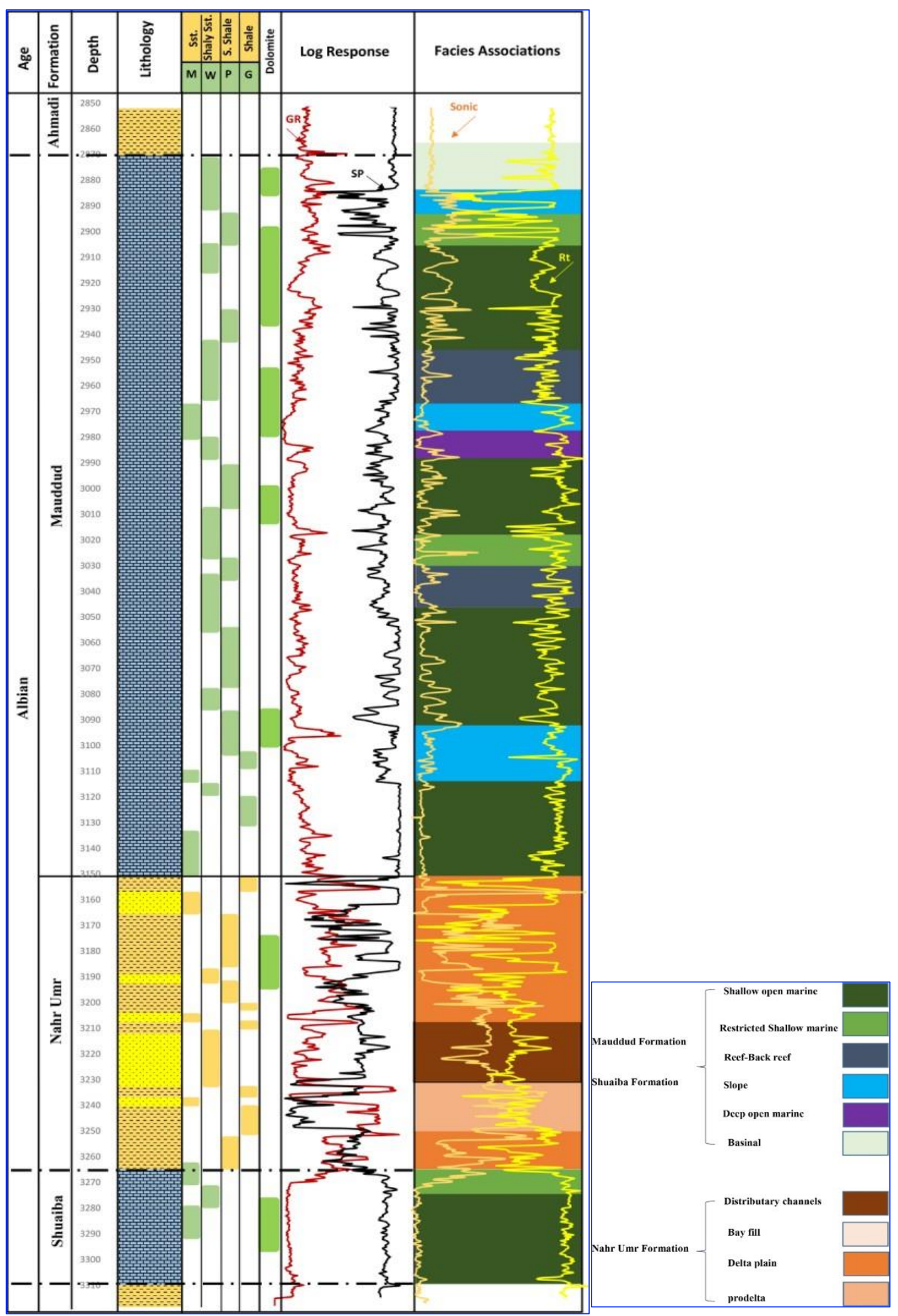

Fig.15. Columnar section (well $\mathrm{Ba}-8$ ) shows the lithofacies distribution and major depositional environments 


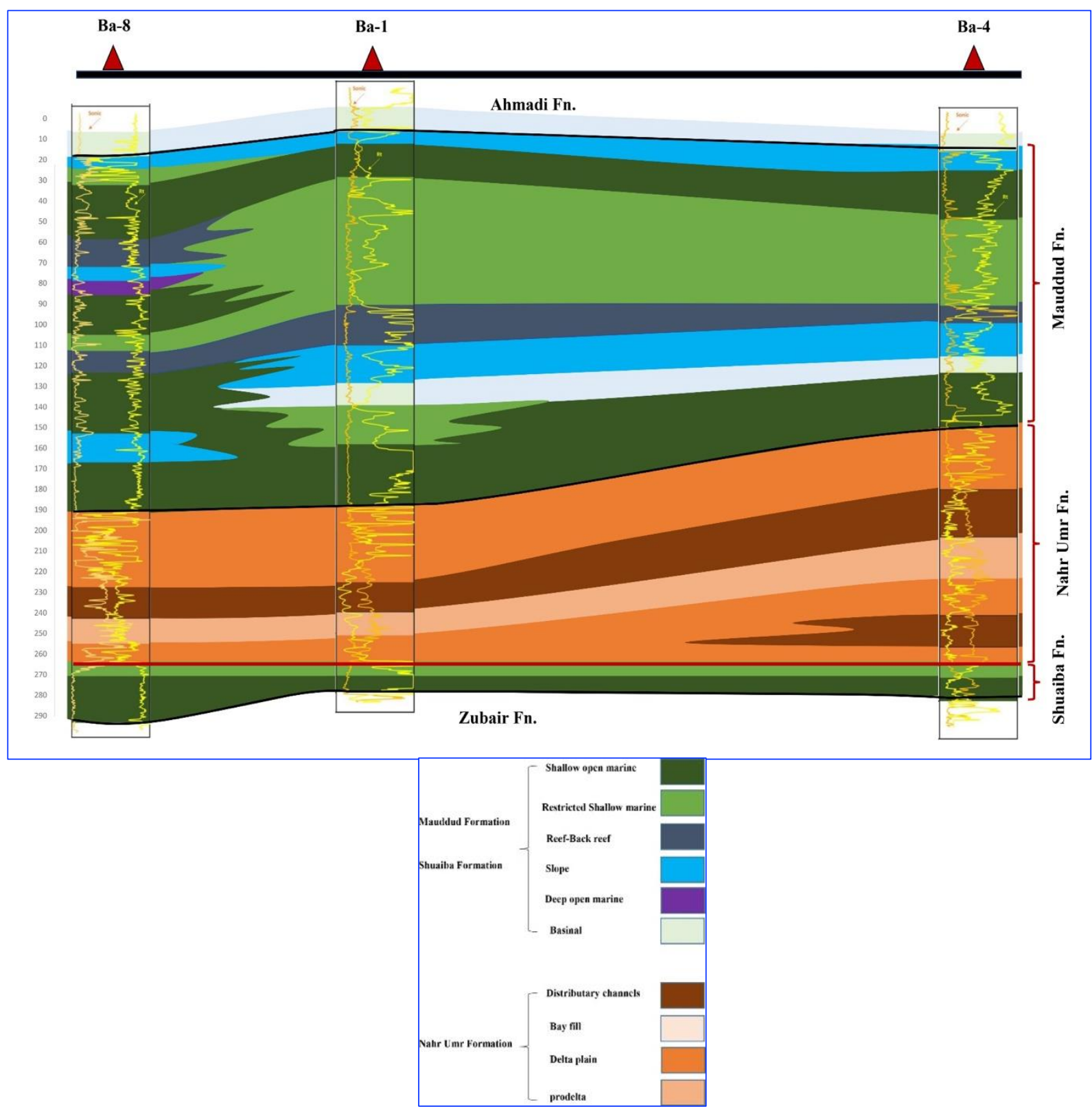

Fig. 16. Cross section shows facies association distributions and major depositional environments

\section{Acknowledgements}

This research was supported by Department of Geology, College of Science, University of Baghdad. We thank our colleagues from oil exploration company (OEC) and especially mention Dr. Muhammed Sulaiman who provided insight and expertise that greatly assisted the research, although they may not agree with all of the interpretations/conclusions of this paper. Authors are very grateful to the Editor in Chief Prof. Dr. Salih M. Awadh, the Secretary of Journal Mr. Samir R. Hijab. and the Technical Editors for their great efforts and valuable comments.

\section{References}

Al-Zaidy A. A., 2019. Facies analysis and sequence stratigraphy of the Zubair Formation in the Kifl oil field, central of Iraq. Iraqi Journal of Science 60, (2), 341-352. 
Bellen, R. C. Van, Dunnington, H. V., Wetzel, R. Morton, D., 1959. Lexique Stratigraphique Internal Asie. Iraq. International Geological Congress Community Stratigraphy 3, Fasc. 1Oa, 333p.

Buday, T., 1980. The Regional Geology of Iraq, Vol 1 Stratigraphy and Paleogeography. Publications of Geological Survey of Iraq, Baghdad, 445 p.

Burchette, T. P. Britton S. R., 1985. Carbonate facies analysis in the exploration for hydrocarbons: a case study from the Cretaceous of the Middle East. In, P.J. Brenchley and B.P.J. Williams (Eds.), Sedimentology: Recent Developments and Applied Aspects, p. 311-338.

Douban, A. F. Medhadi, P., 1999. Sequence chronostratigraphy and petroleum systems of the Cretaceous Megasequences, Kuwait. AAPG International Conference and Exhibition, 152-155.

Dunham, R. J., 1962. Classification of carbonate according to depositional texture, in Ham, W.E. (ed.), Classification of carbonate rocks. AAPG Memoir 1,108-121.

Dunnington, H. V, 1958. Generation, accumulation, and dissipation of oil in Northern Iraq. In Weeks, L. G. (ed.) Habitat of Oil, AAPG, Tulsa, Oklahoma, USA,1194-1251.

Embry, A.F. Klovan, J. E.,1971. A late Devonian Reef tract on northeastern Banks Island. Canadian Petroleum Geology 19, 730-781

Flugel, E., 2010. Microfacies of Carbonate Rocks, Analysis, Interpretation and Application. Springer-Verlag, Berlin, 976 p.

Folk, R. L., Andrews, P.B., Lewis, D. W., 1970. Detrital sedimentary rock classification and nomenclature for use in New Zealand: New Zealand Journal of Geology and Geophysics13, 937-968.

Fouad, S. F., 2014. Tectonic Map of Iraq, Scale 1 1000000. 3rd Edition, Iraq Geological Survey (GEOSURV) Publications, Baghdad.

Jassim, S. Z., Buday, T., 2006. Late Tithonian-Early Turonian Megasequence AP8, chapter 11, In, Jassim S Z. and Goff J.C. (eds.), Geology of Iraq, Dolin, Prague and Moravian Museum, Brno, 124-140.

Muhsin S. U., 2012. 3D Seismic Structural Study of Subsurface in Balad Oil Field - Center of Iraq. University of Baghdad, College of Sciences, department of Geology. M.Sc. unpublished thesis, 133p.

Pettijohn, F. J., Potter, P. E., Siever, R. ,1973. Sand \& Sandstone, Springer -Verlag, Berlin, 618 p.

Powers, M. C., 1953.A new roundness scale for sedimentary particles. Journal of Sediment Resources 23,117119.

Sissakian, V. K., 2000. Geological Hazards in Iraq. Proceedings of the 1st National Symposium of the Iraqi Nuclear Commission for Environmental Pollution and Protection, 5 - 6 / 11/ 2000, Baghdad, Iraq.

Wilson, J. 1., 1975. Carbonate facies in the geological history. Springer-Verlag, New York, 439p. 